\title{
Non-multiplicative attentional modulation patterns in area MT
}

\author{
Markus Helmer ${ }^{1,3^{*}}$, Vladislav Kozyrev ${ }^{2,4}$, Anja Lochte ${ }^{2,3}$, Stefan Treue ${ }^{2,3}$, Theo Geisel ${ }^{1,3}$, Demian Battaglia ${ }^{1,3^{*}}$ \\ From Twenty Second Annual Computational Neuroscience Meeting: CNS*2013 \\ Paris, France. 13-18 July 2013
}

We analyzed single unit recordings in area MT from macaque monkeys performing an attentional task. They were presented a stimulus made out of two moving random-dot-patterns (RDP) within the receptive field of the recorded MT cell. In one experiment the two RDPs were spatially separated, in another they were overlapping at the same location. Attention was directed to a fixation spot or to only one of the two RDPs. The angle between the two RDPs was kept fixed at 120 degrees so that covarying the motion directions provided tuning curves with two peaks.

Using a combination of model-based and model-free approaches we found a variety of non-multiplicative effects, including significant differences between the two experimental conditions, underlying the integration of two stimuli and attentional modulation, such as changes in peak position and shape.

In order to understand these effects we explore multiareal network models with multiple coupled rings, in which functional interactions between hypercolumns of area MT and lower hierarchical order, like V1, are taken into account. We derive a parameterization of a highdimensional manifold representing possible coupling mechanisms which is constrained by data from the two experiments we analyzed. This allows the identification of qualitative correlation patterns between local and inter-areal functional interactions and attentional spotlight mechanisms in our modeling framework.

\section{Acknowledgements}

Volkswagen Foundation (grant I/79868)

Bernstein Center of Computational Neuroscience Göttingen (grants

01GQ0433 and 01GQ1005C) of the BMBF and the German Research

\footnotetext{
* Correspondence: markus@nld.ds.mpg.de; Demian@nld.ds.mpg.de

${ }^{1}$ Max Planck Institute for Dynamics and Self-Organization, Göttingen, Germany

Full list of author information is available at the end of the article
}

Foundation (DFG) Collaborative Research Center 889 "Cellular Mechanisms of Sensory Processing"

\section{Author details}

${ }^{1}$ Max Planck Institute for Dynamics and Self-Organization, Göttingen, Germany. ${ }^{2}$ Cognitive Neuroscience Laboratory, German Primate Center, Göttingen, Germany. ${ }^{3}$ Bernstein Center for Computational Neuroscience, Göttingen, Germany. ${ }^{4}$ Institute of Neuroinformatics, Ruhr-University, Bochum, Germany.

Published: 8 July 2013

\section{doi:10.1186/1471-2202-14-S1-P20}

Cite this article as: Helmer et al: Non-multiplicative attentional modulation patterns in area MT. BMC Neuroscience 2013 14(Suppl 1):P20.

Submit your next manuscript to BioMed Central and take full advantage of:

- Convenient online submission

- Thorough peer review

- No space constraints or color figure charges

- Immediate publication on acceptance

- Inclusion in PubMed, CAS, Scopus and Google Scholar

- Research which is freely available for redistribution

Submit your manuscript at www.biomedcentral.com/submit

\section{() Biomed Central}

\section{() Biomed Central}

